\title{
Does Financial Performance Matter? Evidence on the Impact of Liquidity and Firm Size on Stock Return in Indonesia
}

\author{
Mochammad Chabachib ${ }^{1}$, Ike Setyaningrum ${ }^{1}$, Hersugondo Hersugondo ${ }^{1}$, Intan Shaferi ${ }^{2} \&$ Imang Dapit Pamungkas $^{3}$ \\ ${ }^{1}$ Business and Economics Faculty, Universitas Diponegoro, Semarang, Indonesia \\ ${ }^{2}$ Business and Economics Faculty, Universitas Jenderal Soedirman, Purwokerto, Indonesia \\ ${ }^{3}$ Business and Economics Faculty, Universitas Dian Nuswantoro, Semarang, Indonesia \\ Correspondence: Hersugondo Hersugondo, Business and Economics Faculty, Universitas Diponegoro, Semarang, \\ Indonesia. Tel: 62-8-9967-1000. E-mail: hersugondo@lecturer.undip.ac.id
}

Received: November 27, 2019

doi:10.5430/ijfr.v11n4p546
Accepted: February 20, 2020

Online Published: July 15, 2020

URL: https://doi.org/10.5430/ijfr.v11n4p546

\begin{abstract}
In the modern era, stock investment can attract domestic investors or foreign investors. The objective is to invest their funds at the capital market that expect higher stock returns. The study aims to analyze factors that can affect stock returns and know the mediating effect of return on equity. The object of this research is the property and real estate sector that is listed on the Indonesia Stock Exchange from 2013 to 2018. This research used debt to equity ratio, current ratio, total asset turnover, firm size as independent variables and stock returns as dependent variables. Path analysis is used as reseach method tools with SMART PLS.

The result says that debt to equity ratio and return on equity has a positive significant relationship with stock return, meanwhile firm size has a significant negative significant relationship with stock returns. Furthermore, return on equity can mediate the relationship between debt and equity ratios to stock returns.
\end{abstract}

Keywords: financial performance, liquidity, firm size, stock return

\section{Introduction}

It is noticeable that in the modern era, the stock investment becomes one thing that can attract the attention both of domestic and foreign investors. Through expectations, investing funds in the capital market is aimed at high interest returns (Anwaar, 2016). The return on investment in the capital market comes from two sources, capital gains for a short-term investment and dividend for a long-term investment (Iskandar, 2017). There has been lot of research being conducted to know the variables that can predict the stock return. Some previous study used macroeconomic factor to predict such world oil price (Chabachib et al., 2019). On another perspective, fundamental performance which is assessed using accounting data is not included in a stock price. However, company managers become focused in achieving the company's core goals such as maximize shareholder wealth (Laksana \& Hersugondo, (2016); (Utomo et al., 2018). Then, the fundamental variable can predict the relationship between variables, financial ratio is very important variable (Chabachib et al., 2020; Gamayuni, 2015; Isgiyarta et al., 2019; Pamungkas et al., 2018). The financial ratio in previous periods can be considered for an investment decision by comparing other different information (Meesuwan, 2015). Hence, this research uses various financial ratios such as profitability, solvency, liquidity and activity.

Profitability ratios are ratios used by companies to measure how much in generating profits (Chabachib et al., 2019; Irwandi et al., 2019). Arora \& Sharma, (2016); Irwandi et al., (2019) stated that the profitability ratio which is capable of identifying firms to provide a long-term return is Return on Equity (ROE). A research by Anwaar, (2016) stating when the value of ROE increases, then the value of stock return will be high and this finding supports the research by (Petcharabul \& Romprasert, 2014). Meanwhile, another research proposed by Steklá \& Gryčová, (2016) saying that the company's revenue is not used for investment activity, where the higher the investment opportunity, the higher profit will be produced by the company. Anwaar, (2016) who had a different result stating that ROE on stock returns is no effect. Furthermore, Solvency is able to assess in paying off long debt and predict risk of bankruptcy of the company. Leverage Ratio measurement using DER, when the DER ratio high becomes optimal and higher stock return (Abdullah, 2015). In a study conducted by Alexakis et al., (2010) DER on stock returns has a negative effect. 
Liquidity is capable in converting non-cash assets to cash assets (Aga et al., 2013). Choi \& Sias, (2012), stated current ration can help the investors to predict a higher stock return. Also, a research by Gharaibeh et al., (2015) states the results of research that has been done namely the current ratio significantly negative effect on stock returns. A different opinion by Jabbari \& Fathi, (2014) stating that CR does not significantly affect on stock return. Activity ratios are often used when the operational activity of sales and revenue is running and in predicting the rate of return of a stock (Arkan, 2016). The companies with a smaller size tend to be more risky than those that have more sizes. This situation can lead to a higher stock return on the large firms (Er \& Vuran, 2012; Idris \& Bala, 2015). The size company proxied total asset (Dang et al., 2018). Both property and real estate sectors are based on the sectoral returns per sector in one period of 2014-2015, property and real estate sectors declined sharply compared to other sectors by $60.81 \%$. There are differences in performance on each company from year to year, but there are times when the company's performance stagnates or fluctuates. Based on the description explained above, the research problem in this study is the inconsistency on the average of DER, CR, total asset turnover, firm size, ROE, and stock returns on property and real estate firms, and the inconsistency toward the result in previous research on DER, CR, total asset turnover, firm size of stock returns in where ROE conducts as intervening variable.

\section{Literature Review and Hypotheses Development}

\subsection{Literature Review}

Signaling theory fundamentally focuses reducing information gaps between two companies, both companies and non companies (Connelly \& Ireland, 2011). Signaling is a theory that serves to explain that the financial statement has a function as a indicator of a positive or negative signal of a company by the users. The economical scale is the condition where the output growth is twice as fast as the input, in which if the input price is constant so the cost per unit of output will be lower and the result scale will increase. The companies with a larger output have a different technique with the company having a lower output scale (Woudstra et al., 2017). According to (Irwandi et al., 2019; Sari et al., 2020; Tristiarini et al., 2017), the company emphasizes the theory of economies of scale as a factor that determines the optimal company size and implies the increased profitability.

\subsection{Hypotheses Development}

\subsubsection{Debt Equity Ratio on Return on Equity}

Financial Leverage is measured based on DER ratio on a company (Chabachib et al., 2019). The estimated cost of bankruptcy and the protection of tax interest due to debt are more valuable in a company with high profitability, which increases due to the tax shield utilization and ability to pay its debt and interest. According to Yuniningsih et al., (2019), increase in debt, leads to a rise in performance and profitability. A study conducted by Mirza, (2013) stated that DER profitability has a positive and significant relationship with ROE, which encourages directors to develop their strategy to gain more profits. Therefore, its purpose is to provide satisfaction to creditors and also attract new investors. The result of this study supports the research conducted by Kamar (2017).

\section{H1: Debt to equity ratio has a significant positive effect on return on equity}

\subsubsection{Current Ratio on Return on Equity}

The current ratio is defined as short-term liquidity and when it is high, the liquidity level increases. Liquidity is measured by the current ratio in planning and controlling assets and debt to minimize risk. Therefore, a company is able to pay off short-term corporate debt, however, it reduces profitability (Khaddafi \& Heikal, 2014). Mirza (2013) in their research stated that Current Ratio has a significant negative effect on ROE. Higher liquidity value indicates that assets are not utilized properly, however, when properly utilized it generates profits for the company. The result of this study is supported by research conducted by Ismail (2016).

$\mathrm{H} 2$ : Current ratio has a significant negative effect on return on equity

\subsubsection{TATO on Return on Equity}

Total asset turnover is a ratio related to sales value, and a company efficient and effective use of its assets (Citta et al., 2019). Total asset turnover is a ratio used to measure a company's ability to maximize its assets and how quickly they are returned. When it is faster efficiency is achieved. The results of the study conducted by Mubin et al., (2014) stated that between the three components of the identification, total asset turnover has the most influence on ROE, where TATO is related to the internal factors of the firm. These findings are consistent with the results of research conducted by Jabbari \& Fathi, (2014) which stated that total asset turnover has a significant positive effect on equity.

H3: TATO has a positive effect on return on equity

\subsubsection{Firm Size on Return on Equity}

The firm size is proxied with the total assets, therefore, based on the economics of scale, when it is large it has the 
potential to reduce costs associated with productivity, by running long-term production. Mirza (2013) stated that size has a significant positive effect on return on equity. In addition, the findings carried out in accordance with research conducted by Mule et al., (2015) reported that a company's success is determined by its economic scale, which leads to higher profit.

H4: Firm size has a positive effect on return on equity

\subsubsection{Return on Equity on Stock Return}

The signalling theory suggests that firms with high profitability use equity as a signal to investors, which means that they are performing properly. Chen, (2017) stated that those with higher ROE grow faster compared to those with lower ROE. Research by Petcharabul \& Romprasert, (2014) on profitability with stock returns stated that ROE has a significant positive effect on stock returns. The results of this study are consistent with the findings of the study conducted by Pik Har \& Ghafar, (2015) which stated that generally, ROE is the best measurement among profitability ratios in predicting stock returns.

\section{H5: Return on equity has a positive effect on stock return}

\subsubsection{Debt to Equity Ratio on Stock Return}

An increase in DER has an impact on the high general risk of equity, therefore, the higher the DER, the higher the risk. The high debt will make the company improve its performance to repay its debt, therefore, it leads to an increase in return. The amount of debt possessed by the company leads to tax storage and for its cash flows that impact on improving performance (Utomo \& Pamungkas, 2018). Based on the theory of signalling, an increase in debt is a positive signal and vice versa (Luffarelli, 2018). De Haan \& Vlahu, (2016) stated that the lower the DER of a company, the lower the return, and the higher the DER and stock return. This is supported by a research conducted by Idris \& Bala, (2015) which stated that DER has a significant positive relationship with stock returns (Utomo et al., 2018).

H6: Debt equity ratio has a positive effect on stock return

\subsubsection{Current Ratio on Stock Return}

Liquidity is a representation of the company's ability to pay its short-term liabilities. Therefore, better liquidity leads to enhanced operational value with low liquidity. However, higher CR indicates the inefficiency of the company is using its cash and short term assets (Jermsittiparsert et al., 2019). High liquidity gives a negative signal to the market because it indicates the amount of cash that is not used in the activity (Robinson et al., 2011). Gharaibeh et al., (2015) stated that CR had a significant and negative effect on stock return. This is supported by the research conducted by Salehi et al., (2011) which stated that the investors tend to choose companies with a decreased CR because they aim for higher stock return.

H7: Current ratio has a negative effect on stock return

\subsubsection{TATO on Stock Return}

Asset turnover is one of the ratios used to explain the efficiency of company management. According to Gitman and Zutter, the increase in turnover ratio indicates efficiency in the use of assets with a low turnover ratio. Based on the signalling theory, the change from the value of total asset turnover provides a signal of improvement in the firm's performance, therefore, a high stock return is obtained. Alexakis et al., (2010) stated that the higher the TATO value, the higher the stock returns because it shows the more efficient use of assets. This result is supported by research by Jabbari \& Fathi, (2014) which stated that TATO has a significant positive effect on stock returns.

H8: Asset turnover has a positive effect on stock return

\subsubsection{Firm Size on Stock Return}

The firm size is the sum of a company's production capacity and ability to provide the needs required by customers. Its size allows for an impact on returns and those with a larger scale tend to earn greater profits (Chabachib et al.,, 2019; Duy \& Huu Phuoc, 2016). According to Er \& Vuran (2012), firms with larger sizes are more successful. This is supported by a research conducted by Hoang et al., (2015) which stated that size has a significant positive relationship with stock returns.

\section{H9: Firm Size has a positive effect on stock return}

\subsubsection{Return on Equity Mediates the Relationship Between Debts to Equity Ratio on Stock Return}

Based on the balancing theory, the higher the debt owed by a company, the greater the profitability. In addition, managers opt to choose specific capital structure targets based on profit and debt costs. The main point of balancing theory is to the use of debt financing, to receive a protector for tax interest and some other benefits. When the 
leverage is low, the chances of financial difficulties decreases, and when the result of the cost of debt is low, profitability increases (Parrino et al., 2011). This is supported by the result of a research conducted by Mirza, (2013) which reported that the use of debts encourages profitability. Kamar, (2017) stated that DER has a significant positive effect on stock return because the lower its value the lower the stock return. A research conducted by Agrawal et al., (2019) reported that ROE mediates the relationship between DER and stock returns.

H10: Return on equity mediate the relationship between debt to equity ratio and stock returns

\subsubsection{Return on Equity Mediates the Relationship Between Current Ratio and Stock Return}

Mirza, (2013) reported that the current ratio has a significantly negative effect on equity. Increased liquidity means that the company's assets are not properly maximized. Based on signalling theory, to avoid any information gap, companies with high liquidity voluntarily provide more information to investors. This provides a negative signal to the market because it indicates the amount of cash that is not used in the activity (Ismail, 2016). Jermsittiparsert et al., (2019) stated that the current ratio has a significant and negative effect on stock return. Artani, (2017); Hardika et al., (2018) reported that companies with high ROE are able to maintain their growth rate without borrowing or issuing additional shares. In research conducted by Petcharabul \& Romprasert (2014), stated that ROE has a significant positive relationship to stock returns.

H11: Return on equity mediates the current ratio on stock return

\subsubsection{Return on Equity Mediates the Relationship Between Total Asset Turnover and Stock Return}

TATO is influenced by the value of both sales and total assets, which indicates the efficiency of the company is using its total assets. Based on Dupont analysis, total asset turnover is a component that affects ROE. Total asset turnover is the component with the greatest influence on ROE, therefore, the higher the value, the higher the return on equity (Mubin et al., 2014). Based on a signal theory, the changes in total asset turnover value owned by a company is able to provide a positive signal on the investor's positive signals from a company. According to Gamayuni (2015), a higher value of total asset turnover leads to an increase in the company's performance. In addition, Jabbari \& Fathi, (2014) and Petcharabul \& Romprasert, (2014) stated that TATO has a significant and positive effect on stock return. Jermsittiparsert et al., (2019) stated that companies with high ROE is able to maintain its growth rate without borrowing or issuing additional shares (Utomo et al., 2018).

H12: Return on equity can mediate total asset turnover on stock return

\subsubsection{Return on Equity Mediates Firm Size on Stock Return}

Based on the theory of economies of scale and statements derived from Chowdhury \& Chowdhury, (2010), firms with larger sizes have several advantages such lower taxes which leads to minimal capital used for operations with a greater susceptibility to selling bonds and stocks to raise more funds. Abdullah, (2015) conducted a study of the firm size relationship to ROE, which showed a significant positive effect on equity. The bigger the company the better it tends to affect the stock price. A research conducted by Chabachib et al., (2019); Utomo \& Pamungkas, (2018) stated that those with larger sizes are successful due to higher stock return.

H13: Return on equity mediate the relationships between firm size and stock return

Here the research model is shown in Figure 1. The relationship among variables and the hypotheses are as follows:

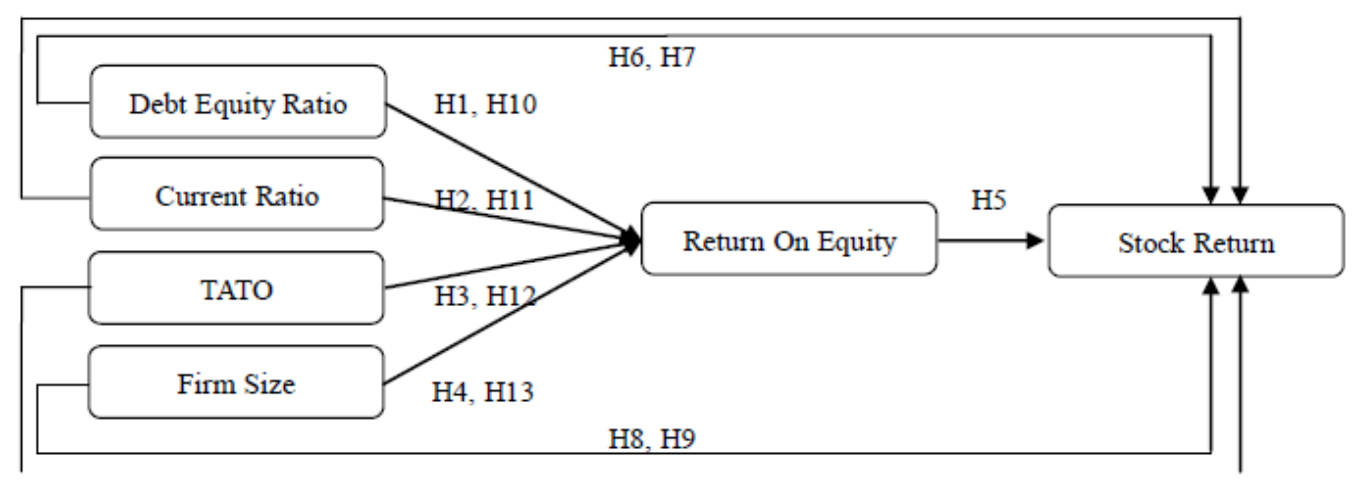

Figure 1. Theoritical framework 


\section{Method}

The secondary data used are annual and financial reports of companies that focus on property and real estate listed on the Indonesia Stock Exchange from 2013-2018 based on the Indonesia Capital Market Directory (ICMD), financial statements from BEI, Bloomberg, and www.idx.com. Data were obtained from a total sample of 43 companies. Furthermore, the analysis was conducted by using pooling data, with the partial Least Square (PLS) used to test for hypotheses. Furthermore, the study used multiple linear regression models for its analysis. The variables operational definitions are shown in Table 1.

Table 1. Variable operational definitions

\begin{tabular}{|c|c|c|c|c|}
\hline Variable & Proxy & Information & Formula & References \\
\hline $\begin{array}{l}\text { Stock } \\
\text { Return }\end{array}$ & $\mathrm{P}_{\mathrm{t}}-\mathrm{P}_{\mathrm{t}} \mathrm{P}_{\mathrm{t}-1}$ & $\begin{array}{l}\text { Stock return in form of annual capital } \\
\text { gain, with the stock price formula for } \\
\text { the current year period reduced with } \\
\text { the previous share price then divided } \\
\text { by the stock price of the previous } \\
\text { period. }\end{array}$ & $\begin{array}{l}\text { Stock price of current period- } \\
\text { Stock price of current period- } \\
\text { Stock price of previous period }\end{array}$ & $\begin{array}{l}\text { (Jogiyanto, } \\
\text { 2000) }\end{array}$ \\
\hline $\begin{array}{l}\text { Debt to } \\
\text { Equity } \\
\text { Ratio }\end{array}$ & DER & $\begin{array}{l}\text { Ratio of total debt, either at both } \\
\text { short-term or long-term where the } \\
\text { company with total equity used to } \\
\text { present how a company owning its own } \\
\text { capital can guarantee the overall debt } \\
\text { of the company. }\end{array}$ & $\begin{array}{l}\text { Calculated by total liabilities } \\
\text { divided by shareholder equity }\end{array}$ & $\begin{array}{l}\text { Horne \& } \\
\text { Wachowicz, } \\
\quad(2001)\end{array}$ \\
\hline $\begin{array}{l}\text { Current } \\
\text { Ratio }\end{array}$ & $\mathrm{CR}$ & $\begin{array}{l}\text { ratio that has a function to explain the } \\
\text { amount of current liabilities of the } \\
\text { company whose payment is guaranteed } \\
\text { by current assets. }\end{array}$ & $\begin{array}{l}\text { Calculated by current assets } \\
\text { divided by current liabilities }\end{array}$ & $\begin{array}{l}\text { Horne \& } \\
\text { Wachowicz, } \\
\text { (2001) }\end{array}$ \\
\hline $\begin{array}{l}\text { Total } \\
\text { Assets } \\
\text { Turnover }\end{array}$ & TATA & $\begin{array}{l}\text { Total Assets Turnover ratio is the asset } \\
\text { turnover or sales to asset ratio that } \\
\text { serves to show how well the company's } \\
\text { assets in generating sales, the formula } \\
\text { used is the sales divided by the average } \\
\text { total assets of the current period with } \\
\text { the total assets of the previous period. }\end{array}$ & $\frac{\text { Sales }}{\left(\text { Total asset }_{\mathrm{t}}+\text { Total }^{\text {Asset }}{ }_{\mathrm{t}-1}\right) / 2}$ & $\begin{array}{l}\text { Al-Khazali } \\
\text { \& Zoubi, } \\
\quad(2005\end{array}$ \\
\hline $\begin{array}{l}\text { Firm } \\
\text { Size }\end{array}$ & Size & $\begin{array}{l}\text { Firm size can determine the level of } \\
\text { ease of the company to obtain capital } \\
\text { from the capital market, because the } \\
\text { greater the company, the greater the } \\
\text { company's opportunity to sell shares } \\
\text { and bonds. }\end{array}$ & Log Total assets & $\begin{array}{l}\text { Sawir, } \\
\text { (2004) }\end{array}$ \\
\hline $\begin{array}{l}\text { Return } \\
\text { on } \\
\text { Equity }\end{array}$ & ROE & $\begin{array}{l}\text { Return on Equity is a variable that acts } \\
\text { as a mediator between independent } \\
\text { variables and dependent variable }\end{array}$ & $\frac{\text { Earning After Tax } \mathrm{x} 100}{\text { Total equity }}$ & $\begin{array}{l}\text { Albercth et } \\
\text { al, (2008) }\end{array}$ \\
\hline
\end{tabular}

Source: output of seconday data processing, 2019

\section{Result and Discussion}

The sampling technique is conducted through the census method, from a total of 55 companies from which 43 were selected using the purposive sampling method in property and real estate. The average value of stock returns in property and real estate companies from 2012 to 2016 was $33.09 \%$ and the standard deviation was $96.40 \%$. The model from the effect of independent variables on ROE with Adjusted R-Square, ROE variability, independent variables, and variability were $0.173,17.3 \%, 82.7 \%$ and 0.169 , respectively. The interpretation that the variability of the construct of stock return is explained by independent construct variability by $16,9 \%$ while $83,1 \%$ is explained. 
T-Statistic for the first model with dependent variable ROE is equal to 2,315 with the P-Values equal to 0,021 and for the second model, it is 2,009 and 0,045, respectively. This study examines the first and second regression models.

Table 2. Path coefficients (Mean, STDEV, T-Value)

\begin{tabular}{ccccrr}
\hline & $\begin{array}{c}\text { Original } \\
\text { Sample }\end{array}$ & $\begin{array}{c}\text { Sample } \\
\text { Mean }\end{array}$ & $\begin{array}{c}\text { Standard } \\
\text { Deviation }\end{array}$ & T Statistics & P Values \\
\hline DER -> ROE & 0,322 & 0,318 & 0,031 & 3,619 & 0,037 \\
\hline DER -> STOCK RETURN & 0,418 & 0,394 & 0,080 & 3,304 & 0,000 \\
\hline CR -> ROE & $-0,064$ & $-0,067$ & 0,031 & 2,085 & 0,037 \\
\hline CR -> STOCK RETURN & $-0,009$ & 0,018 & 0,058 & 0,163 & 0,871 \\
\hline TATO -> ROE & $-0,277$ & $-0,240$ & 0,216 & 1,282 & 0,200 \\
\hline TATO -> STOCK RETURN & $-0,118$ & $-0,110$ & 0,044 & 2,657 & 0,008 \\
\hline SIZE -> ROE & 0,131 & 0,133 & 0,061 & 2,160 & 0,031 \\
\hline SIZE -> STOCK RETURN & $-0,218$ & $-0,216$ & 0,047 & 4,656 & 0,000 \\
\hline ROE -> STOCK RETURN & 0,169 & 0,183 & 0,053 & 3,175 & 0,002
\end{tabular}

Source: output of seconday data processing, 2019

Hypothesis testing is run with the path analysis, by examining its significant value to determine the effect between variables. This test is conducted by comparing the result of T-Statistics calculation with the limit of T-Statistics for $5 \%$ significance to obtain 1,967 .

Based on Table 2, the first regression equation in this model is mathematically represented as follows:

$$
R O E=0,322 \text { DER - 0,064 CR - 0,277 TATO + 0,131 SIZE }
$$

The amount of ROE to RS coefficient is 0,169 , DER to RS is 0,418 , CR to RS is $-0,009$, TATO to RS is $-0,118$, and variable of SIZE to RS is $-0,218$. The value of T Statistic variable from ROE, DER, CR, TATO, and SIZE to RS are $3.175,3.304,0.163,2.657$, and 4,656. Mathematically, the first regression equation in this model is as follows:

$$
R S=0,169 R O E+0,383 D E R-0,009 C R-0,186 \text { TATO - 0,218 SIZE }
$$

The amount coefficient of DER is 0.322 with the T Statistic of 3.619. The t-value is greater than t-table (3.304> 1.967), therefore, it is concluded that hypothesis 1 explained the Debt Equity Ratio which has a significant positive effect on ROE is accepted. The amount of coefficient variable at the current ratio is - 0.064 with t-Statistic at 2.085 because the value of $t$-arithmetic is greater than $t$-table $(2.085>1.967)$. Therefore, it is concluded that in hypothesis 2 the current ratio which has a significant negative significant to ROE is accepted.

The amount of coefficient variable of total asset turnover ratio is 0.277 with the t-Statistic is 1.282 , with a t-value smaller than the t-table $(1.282<1.967)$. Therefore, it is concluded that the hypothesis 3 which stated that total asset turnover ratio has a significant positive effect, therefore, ROE is rejected. The amount of coefficient variable of firm size is 0.131 with the T-statistic of 2.160 which is greater than $t$-value in the table $(2,160>1,967)$. It is concluded that hypothesis 4 which stated that firm size has a significant positive effect on ROE is acceptable, therefore, the amount of ROE coefficient variable is 0.169 with the T-statistic value is 3.175 . When the value of $t$ arithmetic is greater than t-table (3.175> 1.967), it is concluded that hypothesis 5 which stated that ROE has a significant positive effect on the stock return is accepted. The amount of DER coefficient variable is 0.322 with a T-Statistic of 3.304, where the $\mathrm{t}$-value is greater in the table $(3,304>1,967)$. It is concluded that hypothesis 6 which stated that DER has a positive significant effect on stock returns with a coefficient value of -0.009 and $t$-value of 0.163 . Based on these data, it is concluded that the calculated $t$-value is smaller than the $t$-table value $(0.163<1.967)$. Therefore, hypothesis 7 which stated that the current ratio needs to have a significant negative effect on stock returns is rejected.

The coefficient variable of total asset turnover ratio is -0.118 with T-Statistic of 2,657, where the t-value is bigger in the table $(2,657>1,967)$, therefore, hypothesis 8 which results in a turnover of total assets having a significant positive effect on stock returns is rejected. The coefficient variable on firm size is -0.218 with the value of T-Statistic 4.656 where the $t$-count is greater than the value of $t$ in the table (4.656>1.967). The negative sign on the coefficient parameter shows the direction, which means that any increase in firm size, decrease the value of stock return by 0.218 , therefore, hypothesis 9 is rejected. The path analysis result shows that DER directly influences stock return 
and indirectly influenced ROE. The direct and indirect effects of DER to RS are 0.418 , and 0.054 with a total effect of 0.472 .

In another case, the influence of mediation shown by multiplication coefficient (p2 x p3) is 0,054 , then it is conducted that a significant test is conducted to determine its value. The significant test is conducted by Sobel test with the result as follows: p-value of mediation test ROE on the relationship with DER to stock return is 0,017 $(<0,05)$ and the $t$-value count is 2,386 or greater than the value of $t$-table with a significance level of 0.05 at 1.967 . Therefore, it was concluded that the mediation coefficient value of 0.054 , from these calculations, shows that ROE is able to mediate the effect of DER on RS. Based on the results of the total coefficient output, the effect of DER on stock returns is greater when compared to the direct effect of DER on returns. The statistical value of T-Sobel is greater than the calculated t-value, therefore, hypothesis 10 in this study which stated that ROE mediates the effect of DER on stock returns is accepted.

The result of path analysis shows that the current ratio directly/indirectly influences stock return through ROE. The direct and indirect influence of CR to RS are -0.009 and $(-0.064) \times(0.169)=-0.011$, with an effect of $0.009-0.011=$ -0.02 . Influence of mediation shown by multiplication coefficient $(\mathrm{p} 2 \times \mathrm{p} 3)$ is equal to $-0,011$. Therefore, a significant test is conducted to determine significant value. The significant test is conducted with Sobel test of p-value which mediates the ROE on the relationship between current ratio to stock return is $0,081(>0,05)$ and $\mathrm{t}$-count is 1,742 or smaller than $\mathrm{t}$-value in the table where the level of significance 0,05 is 1,967 . It is concluded that the coefficient of mediation -0.011 is insignificant, which indicates that ROE does not mediate CR on RS. Based on the result of the total coefficient in the current ratio on stock return is greater than the direct influence, but the value of T-statistic Sobel is smaller than T-arithmetic, therefore, hypothesis 11 was rejected.

Total assets turnover affect the stock returns indirectly influence ROE. The direct, indirect and total influence of TATO to RS are- $0.118,(-0.277) \times(0.169)=-0.04$, and $0,118-0.04=-0,158$. The effect of mediation shown by multiplication coefficient ( $\mathrm{p} 2 \times \mathrm{p} 3$ ) is $-0,04$, therefore, a significant test is conducted to determine the significant value. The significance test is conducted with a Sobel test and the result of p-value to ROE meditation on the relationship between total asset turnover to stock return is $0.234(>0,05)$. The T-value count is 1.189 or it smaller than $\mathrm{t}$-table with a significance level of 0.05 at 1.967 . Therefore, it is concluded that the mediation coefficient value is -0.04 which means it is not significant, which indicates that ROE does not influence TATO on RS. Based on the results of the total coefficient, the total effect of asset turnover on stock returns is smaller than the direct effect and $\mathrm{t}$-statistic Sobel value is smaller than the T-arithmetic, therefore, hypothesis 12 which stated that ROE mediates the effect between total asset turnovers on stock returns is rejected.

The result of path analysis showed that firm size has a direct effect on stock return and indirectly influenced through ROE. The direct, indirect and total effect of SIZE to RS is $-0.218,(0.131) \times(0.169)=0.02$, and $-0,218+0.02=$ $-0,198$. The effect on mediation showed the multiplication coefficient ( $\mathrm{p} 2 \mathrm{X} \mathrm{p} 3$ ) of 0.02 . Furthermore, a significant test is run to determine the level of its significance using the Sobel test with a p-value on mediation ROE between firm size to stock return at $0.07(>0,05)$ and the $t$-value is 1,785 or it is greater than the $t$-value in the table with the significant level 0.05 is 1,967 .

\section{Conclusion}

The result says that debt to capital ratio and return on equity have a significant positive effect on stock returns, furthermore, company size has a significant negative effect on stock returns. Equity returns are able to mediate the relationship between the ratio of debt to equity to stock returns. Data and models used in this research are feasible to be examine, it is proved by the fit of the test model the results indicate that the model meets the criteria according to coefficient determination and significant test. Of the thirteen hypotheses that have been proposed, there are six acceptable hypotheses.

Limitations in this study do not include a number of external factors such as analyzing the economic and industrial environment during the assessment process. This studies only the fundamental aspects of the company as consideration for investment through securities. Further research, control variables such as inflation, interest rates, and political factors can be included as variables to be examined, so as to be able to add information that is useful for investment decisions in the stock capital market. The next researcher should use daily stock return data obtained a few days before and after the financial statements are announced to reduce the confounding effect.

The advice that given is for investors and investment management in stock purchase decisions not only consider ratio analysis in assessing a return. However, it must also consider factors outside the company's policy such as the current economic conditions because this indirectly affects the benefits to be gained in investing. 
Further researchers are advised to conduct for banking, insurance, agriculture, securities companies, mining, food and beverage, transportation and others sectors. And the research period can be extended to be longer, add research periods so that research results can be generalized, and add one or more variables that affect stock returns.

Companies with high portion of debts are not always bad because the higher the value of debts, so the company must be able to manage the debts they have well. The current assets owned should be used on activities or investments that can generate profits for the company. In addition to this, firm size has a significant positive effect on ROE indicating that the bigger the company, it will be able to improve profitability of the company. The greater the company, it will affect to the low value of the production costs, so it can increase the profit generated. Companies need to maintain the value of ROE in order to increase the value of stock returns, so that investors who want a high stock return should consider the value of a company's ROE. Greater the debt owned by the company can encourage increased performance so as to obtain greater profits. At last, ROE can mediate the effect of DER on stock returns, it indicates that an increase in DER can increase the profits owned by the company and can cause a higher stock return.

\section{References}

Aga, B. S., Mogaddam, V. F., \& Samadiyan, B. (2013). Relationship between liquidity and stock returns in companies in Tehran Stock Exchange. Applied Mathematics and Engineering, Management and Technology, 1(4), 278-285.

Agrawal, A., Mohanty, P., \& Totala, N. K. (2019). Does EVA Beat ROA and ROE in Explaining the Stock Returns in Indian Scenario? An Evidence Using Mixed Effects Panel Data Regression Model. Management and Labour Studies, 44(2), 103-134.

Alexakis, C., Patra, T., \& Poshakwale, S. (2010). Predictability of stock returns using financial statement information: Evidence on semi-strong efficiency of emerging Greek stock market. Applied Financial Economics, 20(16), 1321-1326. https://doi.org/10.1080/09603107.2010.482517

Anwaar, M. (2016). Global Journal of Management and Business Research: D Accounting and Auditing Volume. Impact of Firms' Performance on Stock Returns (Evidence From Listed Companies of Fste100 Index London, $U k), 16(1)$.

Arkan, T. (2016). The Importance of Financial Ratios in Predicting Stock Price Trends: A Case Study in Emerging Markets. Zeszyty Naukowe Uniwersytetu Szczecińskiego Finanse Rynki Finansowe Ubezpieczenia, 1(1), 13-26. https://doi.org/10.18276/frfu.2016.79-01

Arora, A., \& Sharma, C. (2016). Corporate governance and firm performance in developing countries: evidence from India. Corporate Governance (Bingley), 16(2), 420-436. https://doi.org/10.1108/CG-01-2016-0018

Artani. (2017). Pengaruh Academic Self Efficacy dan Fraud Diamond Terhadap Perilaku Kecurangan Akademik Mahasiswa Akuntansi di Bali. Jurnal Riset Akuntansi, 7(2), 123-132.

Chabachib, M., Fitriana, T. U., Hersugondo, H., Pamungkas, I. D., \& Udin, U. (2019). Firm value improvement strategy, corporate social responsibility, and institutional ownership. International Journal of Financial Research, 10(4), 152-163. https://doi.org/10.5430/ijfr.v10n4p152

Chabachib, M., Hersugondo, H., Ardiana, E., \& Pamungkas, I. D. (2019). Analysis of Company Characteristics of Firm Values: Profitability as Intervening Variables. International Journal of Financial Research, 11(1), 60. https://doi.org/10.5430/ijfr.v11n1p60

Chabachib, M., Yudha, A., Hersugondo, H., Pamungkas, I. D., \& Udin, U. (2019). The role of firm size on bank liquidity and performance: A comparative study of domestic and foreign banks in Indonesia. International Journal of Economics and Business Administration, 7(3), 96-105.

Chabachib, M., Hersugondo, H., Hidayat, R., \& Pamungkas, I. D. (2020). Corporate Governance, Firm Performance and Capital Structure: Evidence From Indonesia. 11(1), 48-55. https://doi.org/10.5430/rwe.v11n1p48

Chabachib, M., Kusmaningrum, R. H., Hersugondo, H., \& Pamungkas, I. D. (2019). Financial distress prediction in Indonesia. WSEAS Transactions on Business and Economics, 16(2015), 251-260.

Chen, H. J. (2017). Do Cash Flows of Growth Stocks Really Grow Faster?. Journal of Finance, 72(5), 2279-2330. https://doi.org/10.1111/jofi.12518

Choi, N. Y., \& Sias, R. W. (2012). Why does financial strength forecast stock returns? evidence from subsequent demand by institutional investors. Review of Financial Studies, 25(5), 1550-1587. https://doi.org/10.1093/rfs/hhs001 
Chowdhury, A., \& Chowdhury, S. P. (2010). 10_V3_BEH_BANGLADESH_AnupChowhury_et_al_d_ac.pdf. Business and Economic Horizons, 3(3), 111-122.

Citta, A. B., Ridha, A., Dekrita, Y. A., \& Yunus, R. (2019). Advances in Economics, Business and Management Research (AEBMR), 92(Icame 2018), 119-126.

Connelly, B., \& Ireland, R. D. (2011). Signaling Theory: A Review and Assessment. (September 2014). https://doi.org/10.1177/0149206310388419

Dang, C., (Frank) Li, Z., \& Yang, C. (2018). Measuring firm size in empirical corporate finance. Journal of Banking and Finance, 86, 159-176. https://doi.org/10.1016/j.jbankfin.2017.09.006

De Haan, J., \& Vlahu, R. (2016). Corporate governance of banks: A survey. Journal of Economic Surveys, 30(2), 228-277.

Duy, N. T., \& Huu Phuoc, N. P. (2016). The Relationship between Firm Sizes and Stock Returns of Service Sector in Ho Chi Minh City Stock Exchange. Review of European Studies, 8(4), 210. https://doi.org/10.5539/res.v8n4p210

Er, Ş., \& Vuran, B. (2012). Factors Affecting Stock Returns of Firms Quoted in ISE Market: A Dynamic Panel Data Approach. International Journal of Business and Social Research, 2(1), 108-121.

Gamayuni, R. R. (2015). The Effect Of Intangible Asset Financial Performance And Financial Policies On The Firm Value. International Journal of Scientific \& Technology Research, 4(1), 202-212.

Gharaibeh, A., Khreishah, A., Khalil, I., \& Wu, J. (2015). Asymptotically-optimal incentive-based en-route caching scheme. Proceedings - 11th IEEE International Conference on Mobile Ad Hoc and Sensor Systems, MASS 2014, 318-326. https://doi.org/10.1109/MASS.2014.84

Hardika, A. L., Manurung, D. T. H., \& Mulyati, Y. (2018). Corporate Governance Mechanism, Company Size Financial Performance and Sustainability Reporting. International Journal of Engineering \& Technology, 7(4.34), 201-203.

Hoang, D., Phan, B., Sharma, S. S., \& Narayan, P. K. (2015). Journal of International Financial Markets , Institutions \& Money Oil price and stock returns of consumers and producers of crude oil. Journal of International Financial Markets, Institutions \& Money, 34, 245-262. https://doi.org/10.1016/j.intfin.2014.11.010

Idris, I., \& Bala, H. (2015). Firms' Specific Characteristics and Stock Market Returns (Evidence from Listed Food and beverages Firms in Nigeria). Research Journal of Finance and Accounting, 6(16), 188-201.

Irwandi, S. A., Ghozali, I., Faisal, \& Pamungkas, I. D. (2019). Detection fraudulent financial statement: Beneish m-score model. WSEAS Transactions on Business and Economics, 16, 271-281.

Isgiyarta, J., Nugroho, D. A., Ratmono, D., Helmina, M. R. A., \& Pamungkas, I. D. (2019). Budgetary participation on managerial performance: commitment organization, innovation perception, and job relevant information as mediating variable. Quality - Access to Success, 20(173), 48-53.

Iskandar, M. (2017). Perception of Capital, Profit and Dividends Affect the Stock Purchase Intention in Indonesia Public Company. Junior Scientific Researcher, 3(1), 9-18.

Ismail, R. (2016). Impact of Liquidity Management on Profitability of Pakistani Firms: A Case of KSE-100 Index. International Journal of Innovation and Applied Studies, 14(2), 304-314.

Jabbari, E., \& Fathi, Z. (2014). Prediction of Stock Returns Using Financial Ratios Based on Historical Cost, Compared With Adjusted Prices (Accounting for Inflation) With Neural. Indian Journal of Fundamental and Applied Life Sciences, 4(2003), 1064-1078.

Jermsittiparsert, K., Ambarita, D. E., Mihardjo, L. W. W., \& Ghani, E. K. (2019). Risk-return through financial ratios as determinants of stock price: A study from ASEAN region. Journal of Security and Sustainability Issues, 9(1), 199-210. https://doi.org/10.9770/jssi.2019.9.1(15)

Kamar, K. (2017). Analysis of the effect of return on equity (ROE) and debt to equity ratio (DER) on stock price on cement industry listed in Indonesia stock exchange (IDX) in the year of 2011-2015. IOSR Journal of Business and Management, 19(05), 66-76.

Khaddafi, M., \& Heikal, M. (2014). Financial Performance Analysis Using Economic Value Added in Consumption Industry in Indonesia Stock Exchange. American International Journal of Social Science, 3(4), 219-226. 
Laksana, R. D., \& Hersugondo, H. (2016). Does Economic Value Added Influence the Shareholder Value in Indonesia. International Journal of Applied Business and Economic Research, 14(3), 1547-1560.

Luffarelli, J. (2018). How Do Different Types of Indirect Signals of Corporate Social, 25, 295-310.

Meesuwan, N. (2015). Stock return predict ability with financial ratios: A panel data analysis in the Stock Exchange of Thailand (SET). Faculty of Economics Chulalongkorn University.

Mirza, A. (2013). Determinants of financial performance of a firm: Case of Pakistani stock market. Journal of Economics and International Finance, 5(2), 43-52. https://doi.org/10.5897/jeif12.043

Mubin, M., Lal, I., \& Hussain, A. (2014). Determinant of Return on Assets and Equity and Industry Wise Effects: Evidence from KSE (Karachi Stock Exchange). SSRN Electronic Journal, 5(15), 148-158. https://doi.org/10.2139/ssrn.2372792

Mule, R. K., Mukras, M. S., \& Mutunga, N. O. (2015). Corporate size, profitability and market value: an econometric panel analysis of listed firms in Kenya. European Scientific Journal, 11(13), 376-396.

Nayeem Abdullah, M. (2015). The Impact of Financial Leverage and Market Size on Stock Returns on the Dhaka Stock Exchange: Evidence from Selected Stocks in the Manufacturing Sector. International Journal of Economics, Finance and Management Sciences, 3(1), 10. https://doi.org/10.11648/j.ijefm.20150301.12

Pamungkas, I. D., Ghozali, I., \& Achmad, T. (2018). A pilot study of corporate governance and accounting fraud: The fraud diamond model. Journal of Business and Retail Management Research, 12(2).

Parrino, R., Kidwell, D. S., \& Bates, T. W. (2011). Fundamentals of Corporate Finance, 2 / e Chapter 4: Analyzing Financial Statements.

Petcharabul, P., \& Romprasert, S. (2014). Technology industry on financial ratios and stock returns. Journal of Business and Economics, 5(5), 739-746.

Pik Har, W., \& Afif. Abdul Ghafar, M. (2015). The Impact of Accounting Earnings on Stock Returns: The Case of Malaysia's Plantation Industry. International Journal of Business and Management, 10(4), 155-165. https://doi.org/10.5539/ijbm.v10n4p155

Robinson, D. T., Sensoy, B. A., Phalippou, L., Schoar, A., Sørensen, M., Strömberg, P., \& Stulz, R. (2011). Cyclicality.

Salehi, M., Talebnia, G., \& Ghorbani, B. (2011). A Study of the Relationship Between Liquidity and Stock Returns of Companies Listed in Tehran Stock Exchange. World Applied Sciences Journal, 12(9), 1403-1408.

Sari, M. P., Raharja, S., Yulianto, A., Ardiansari, A., Pamungkas, I. D., \& Achmad, T. (2020). Compliance analysis of asia sustainability reporting awards (Asra) 2018 companies. International Journal of Scientific and Technology Research, 9(3), 3891-3896.

Steklá, J., \& Gryčová, M. (2016). The Relationship between Capital Structure and Profitability of the Limited Liability Companies. Acta Universitatis Bohemiae Meridionalis, 18(2), 32-41. https://doi.org/10.1515/acta-2016-0003

Tristiarini, N., Setiawanta, Y., \& Ririh, D. P. (2017). Optimization of Monetary Corporate Social Responsibility Value Added in Reducing Financial Distress in Indonesia. International Journal of Economics and Financial Issues, 7(2), 500 .

Utomo, S. D., \& Pamungkas, I. D. (2018). Cash flow activities and stock returns in manufacturing of Indonesia: A moderating role of earning management. Academy of Accounting and Financial Studies Journal, 22(6), 1-10.

Utomo, S. D., Pamungkas, I. D., \& Machmuddah, Z. (2018). The moderating effects of managerial ownership on accounting conservatism and quality of earnings. Academy of Accounting and Financial Studies Journal, 22(6), $1-11$.

Woudstra, U., Berghout, E., Tan, C.-W., van Eekeren, P., \& Dedene, G. (2017). Resource Complementarity and IT Economies of Scale: Mechanisms and Empirical Evidence. Information Systems Management, 34(2), 185-199. 